\title{
Exploring the Potential of Customer Accounting: A Synthesis of the Accounting and Marketing Literatures
}

\author{
Lisa McManus* \\ Department of Accounting Finance \& Economics, Griffith University \\ and \\ Chris Guilding \\ Department of Tourism, Leisure, Hotel and Sport Management
}

* Corresponding Author Details

Associate Professor Lisa McManus

Department of Accounting, Finance \& Economics

Griffith Business School

Griffith University - Gold Coast

PMB 50

Gold Coast Mail Centre Q 9726

Australia

Phone: 61755528022

Fax: 61755528068

E-mail: L.McManus@griffith.edu.au

Professor Chris Guilding

Department of Tourism, Leisure, Hotel and Sport Management

Griffith Business School

Griffith University - Gold Coast

PMB 50

Gold Coast Mail Centre Q 9726

Australia

Phone: 617555 28???

Fax: 617555 28???

E-mail: C.Guilding@griffith.edu.au 


\title{
EXPLORING THE POTENTIAL OF CUSTOMER ACCOUNTING: A SYNTHESIS OF THE ACCOUNTING AND MARKETING LITERATURES
}

\begin{abstract}
A review of the marketing and accounting literatures has revealed that to date no previous study has examined the intersection of the marketing and accounting literatures pertinent to Customer Accounting (CA). This paper provides a synthesis of these two literatures by exploring the potential of CA. It updates the recent achievements in the CA literature from an accounting perspective and explores the nature of marketing based measures pertaining to customer marketing and management. It appears there is considerable potential for accountants to draw on points of focus raised in the marketing literature to further advance customer focused accounting measures of performance.
\end{abstract}

Key words: Customer accounting, strategic management accounting, customer satisfaction, customer loyalty, customer profitability. 


\section{EXPLORING THE POTENTIAL OF CUSTOMER ACCOUNTING: A SYNTHESIS OF THE ACCOUNTING AND MARKETING LITERATURES}

\subsection{Introduction}

Customers constitute a fundamental tenet in generally accepted and applied marketing paradigms. This focus on customers appears to be somehow 'lost in translation', however, for those managers aligned to the management accounting paradigm. Management accounting systems tend to be structured according to product, service or geographical territory and rarely according to customer groupings. Further, it appears as a non sequitur for an accounting ledger to recognise a customer or a group of customers as an asset. The disparate way in which customers are conceived of by these two organisational functions highlights the existence of a profound managerial schism. A schism is also in evidence when the findings of Foster and Young (1997) and Shields (1997) are compared. From their survey of American and Australian managers, Foster and Young (1997; p. 69) found that "customer profitability/satisfaction" was the "the single most important current management priority". By way of contrast, in a review of the management accounting literature from 1990 to 1996, Shields (1997) failed to find a single study concerned with 'customer profitability/satisfaction'.

While the extent of customer-focused research conducted from an accounting perspective still fails to rise above minimal attention, some consideration of the potential of accountants adopting a customer focus is now in evidence. Guilding and McManus (2002) conducted a study that stands in relative isolation as a survey concerned with appraising customer accounting (CA) adoption levels and the 
antecedents of CA adoption. Commentaries that provide an overview of the nature and potential of conducting customer profitability analysis include Cardinaels, Roodhooft and Warlop (2004), Chenhall (2003), Foster and Gupta (1994), Foster and Young (1997) and Luft and Shields (2003).

The marketing research concerned with customers appears as endless by comparison. Key points of focus in this literature include customer loyalty, customer retention, customer profitability, and customer satisfaction. Much of this literature provides some implicit dimensions of accountability that could be added to the management accountant's frame of reference. This paper overviews the accounting literature concerned with CA then addresses marketing perspectives most pertinent to CA by considering the marketing literature's achievements with respect to customer satisfaction, customer loyalty and customer profitability.

The paper's objective is to progress a synthesis of the accounting and marketing literatures concerned with CA. In so doing, it points towards techniques and constructs that management accountants might usefully consider in order to advance the way that CA is conceived and conducted (or not conducted). This signifies that the paper represents an attempt to broaden accountants' appreciation of the sphere of possible accountability constructs that can be monitored when determining the marketing function's achievements with respect to customer oriented performance. Although not explicitly addressed in this paper, it is interesting to conjecture the extent to which the conventional accounting mindset that has been characterised as historical and inwardly oriented (Guilding et al, 2000) represents a hindrance to accounting's capacity to view marketing constructs such as customer 
satisfaction and customer loyalty as important dimensions of performance worthy of incorporation in systems of accountability.

The remainder of the paper is structured as follows. The next section places

CA in the broader context of strategic management accounting (SMA). In order to provide a stocktake concerning the current state of the art with respect to customer accounting, and also our knowledge of customer accounting practices applied, the subsequent section attempts a comprehensive overview of the normative and empirical literatures concerning CA. The ensuing section describes the result of an examination of the marketing literature to determine themes most pertinent to CA. This examination has resulted in the distillation of three themes that lend themselves to accountability: customer satisfaction, customer loyalty and customer profitability. In reviewing these themes, prominence has been attached to any discussion relating to facets of performance measurement. The paper's final section provides a discussion and conclusion that explores how the insights provided by this study might be usefully built upon in subsequent research.

\subsection{Customer Accounting - An Example of Strategic Management Accounting}

Customer accounting represents a particular set of practices that can be seen to sit within an accounting subset that has been termed "strategic management accounting". This factor is noteworthy as it appears that the beginnings of an accounting interest in CA, that was noted above, has occurred at a time of a growing appreciation of a need for management accounting to assume more of a strategic orientation. 
It is more than two and a half decades since Simmonds (1981) first coined the term "strategic management accounting" (SMA), however there continues to be limited consensus on its exact meaning (Bhimani and Keshtvarz, 1999; Coad, 1996; Guilding, Cravens and Tayles, 2000; Lord, 1996; Nyamori et al, 2001; and Roslender and Hart, 2003). In commenting on SMA's under-defined nature, Tomkins and Carr (1996) note it also lacks a general conceptual framework. Simmonds (1981) saw SMA as concerned with "the provision and analysis of management accounting data about a business and its competitors for use in developing and monitoring the business strategy" (p. 26). Simmonds extolled management accountants to take more of a strategic perspective and gather information external to the firm that would assist management in strategic operations.

Further conceptualisation of SMA grew from Simmonds work. Bromwich (1990) defined SMA as "the provision and analysis of financial information on the firm's product markets and competitors' costs and cost structures and the monitoring of the enterprise's strategies and those of its competitors in these markets over a number of periods" (p. 28). Lord (1996) identified three dimensions of SMA: collection of competitor information; exploitation of cost reduction opportunities; and matching of accounting emphasis with strategic position. Guilding, Cravens and Tayles (2000) saw SMA practices as exhibiting one or more of the following characteristics: an environmental or marketing orientation; a competitor focus; or a future-looking, longterm orientation. ${ }^{1}$ More recently, Roslender and Hart (2003) provided a more refined definition of SMA as "a generic approach to accounting for strategic positioning,

\footnotetext{
${ }^{1}$ It is noteworthy that these researchers failed to include any CA practices in their survey of SMA practices.
} 
defined by an attempt to integrate insights from management accounting and marketing management within a strategic management framework" (p. 255).

It is notable that SMA practices have been suggested as having the potential to overcome the "fall" of management accounting (Johnson and Kaplan, 1987) and restore the relevance of accounting information provided to the modern day manager (Johnson, 1992). The SMA writings are significant to a consideration of the potential for CA as they highlight a developing awareness of the possibility of accountants assuming more of a strategic posture. This points towards the evolution of an environment that is more conducive to CA inception and development, as CA can be seen to be a particular example of SMA. It is also pertinent to recognize that, consistent with CA, SMA provides considerable impetus for greater communication and collaboration between the accounting and marketing functions (Roslender and Hart, 2003).

\subsection{Customer Accounting - Achievements to Date}

Due to the limited amount of research and commentaries concerned with customer accounting, this section of the paper constitutes an attempt to provide a comprehensive review of all notable contributions to the customer accounting literature. In one of the earliest CA commentaries, Bellis-Jones (1989) discusses customer profitability analysis (CPA) in the context of the retail sector. As a result of a small number of major retailers being able to exert substantial pressure on suppliers to reduce prices, Bellis-Jones noted suppliers initiating activities tailored to certain customers in order to maintain competitiveness. Extending upon this idea, Ward 
(1992) sees CPA as a very important technique due to the increased focus it directs on customers as "the most important assets which a company has" (p. 168). He defines CPA as "the total sales revenue generated from a customer or customer group less all the costs that are incurred in servicing that customer or customer group" (p. 167). Ward argues that most customers require varying levels of customer service, which results in non-revenue related differentials in customer profitability levels. He sees CPA as an important analytical tool that can help firms distinguish between their profitable and unprofitable customers.

Smith and Dikolli (1995) further extend prior CPA discussions with an explicit reference to activity-based costing as a basis for tracing costs to customers. They identify four customer expense categories: purchasing patterns, delivery policy, accounting procedures and inventory holding. Each of these factors carries implications for a customer's profitability and a number of profitable and unprofitable customer characteristics can be identified within each category. Smith and Dikolli suggest that while a number of these characteristics can be directly traced and allocated to customers, other costs are more difficult to determine for each customer, and that these costs warrant the application of an activity-based costing approach.

Guilding, Kennedy and McManus (2001) extended the CA literature by investigating particular CA applications arising in the context of the hotel industry. Guilding et al describe a technique that they refer to as "supplementary purchasing CPA" and explore the application of the technique by way of a hypothetical case study. This exposition demonstrates the potential importance of appraising revenue generating activities occurring after an initial hotel room sale. These "supplementary" 
sources of revenue include restaurant meals, bar sales, telephone calls, and room service. Guilding et al then promote the idea of segmenting a hotel's customer base according to differentials apparent in customer purchasing patterns of such "supplementaries". They also explore the potential of customer asset accounting (CAA) in the context of hotel management.

In terms of applied applications of CPA, Cooper and Kaplan (1991a, 1991b, 1991c) describe three CPA case studies: Kanthal, Winchell Lighting Inc., and Manufacturers Hanover Corporation. Adoption of CPA in these three companies, either on a customer or customer segment basis, was motivated by a quest to identify profitable customer relationships that should be maintained and enhanced, as well as unprofitable customer relationships, to enable the initiation of actions designed to transform the accounts to a profitable standing or to terminate the trading relationship. The "Blue Ridge Manufacturing" case study, which was documented by Juras and Dierks (1994), was further analysed by Foster, Gupta and Sjoblom (1996) who undertook an $\mathrm{ABC}$ based $\mathrm{CPA}$ analysis and found that the largest customer segment which contributed $38 \%$ of the total company revenues, provided over $67 \%$ of the total operating income; and the small customer segment which represented $39 \%$ of company revenues, yielded a negative contribution towards operating income. Foster et al. (1996) noted several key issues arising from this case study. Firstly, that most management accounting systems only focus on products or departments and not on customers, and only seldom can a management accounting system produce customer profitability figures. Secondly, a customer's profitability depends not only on the product or service unit cost, but also on other costs such as marketing, customer service, and distribution. Additional applied CPA case studies 
have been conducted by McManus (2007) in a telecommunications company, Mulhern (1999) in three sales territories of a pharmaceutical manufacturer and Noone and Griffin (1999) in an Irish hotel.

Foster and Gupta (1994) undertook a broad overview of the interaction between the marketing and management accounting literatures concerned with the management of marketing costs. They also examined the opinions of marketing managers with respect to the value of the type of information made available by conventional accounting systems. Foster and Gupta identify a number of central themes, two of which are particularly relevant to customer accounting: the marketing focus on retaining profitable customers and the questionable accounting treatment of all marketing costs as period expenses. The authors also note that a minimally explored dimension of CPA is the lifetime profitability analysis of customers.

Guilding and McManus' (2002) study that investigated the incidence, perceived merit and antecedents of CA in a sample of Australian publicly listed companies stands in isolation in the literature as a survey of CA application. Three main findings were distilled from the study. Firstly, mean scores for three of the five CA practices appraised in the study were above the mid-point of the "used not at all - used to a large extent" measurement scale. ${ }^{2}$ From this observation it was concluded that CA usage was greater than what might have been reasonably anticipated. In addition, mean scores of the perceived merit of all five CA practices appraised were above the mid-point of the measurement scale. The study's other main findings concerned an

\footnotetext{
${ }^{2}$ The five CA practices appraised in the study were customer profitability analysis, customer segment profitability analysis, lifetime customer profitability analysis, valuation of customers or customer groups as assets, and customer accounting (i.e. holistic notion). One of the limitations of the Guilding and McManus (2002) study is that each of the CA practices was measured by a single item.
} 
observed positive association between market orientation and CA, and a weak positive association between competition intensity and CA, although no support was found for a hypothesised inverted- $U$ relationship between $C A$ and competition intensity. Lind and Strömsten (2006) have added to the Guilding and McManus study by developing a framework to explain a company's choice of CA technique based on its customer resource interfaces.

It appears as highly significant that there are a growing number of accounting researchers appraising other customer related factors and non-financial performance measures such as customer loyalty, customer satisfaction, customer complaints, likelihood of return and market share (e.g., Banker, Potter and Srinivasan, 2000; Banker and Mashruwala, 2007; Cugini, Carù and Zerbini, 2007; Davila and Foster, 2005; Ghosh, 2005; Ismail, 2007; Ittner and Larcker, 1998; Perera, Harrison and Poole, 1997; Riley, Pearson and Trompeter, 2003; Smith and Wright, 2004). Perera et al. (1997) extended a study conducted by Abernethy and Lillis (1995) by examining whether companies that pursue a customer-focused manufacturing strategy also emphasise non-financial operations-based performance measures, and whether this emphasis results in improved company performance. The authors provided support for Abernethy and Lillis' findings concerning a positive association between a customer-focused manufacturing strategy and greater use of non-financial performance measures, but no support was found for the hypothesised link to improved company performance.

Ittner and Larcker (1998) focused exclusively on customer satisfaction as a lead indicator of a firm's financial performance and its value relevance using customer, business-unit and firm-level data. They found some support for their 
hypotheses that customer satisfaction is an indicator of customer purchase behaviour (measured by retention, revenue and revenue growth), growth in customer numbers and financial performance (measured by business-unit revenues, return on sales and profit margins). Evidence was also provided that customer satisfaction measures hold some value for stock markets but are not completely reflected in accounting book values. Ittner and Larcker also found that the relationship between customer behaviour (measured by retention, revenue and revenue growth) and financial performance are relatively stable over different ranges of customer satisfaction, but tend to diminish at high customer satisfaction levels.

Banker et al. (2000) investigated the performance impacts of using customer satisfaction (measured by the likelihood of return and customer complaints) in hotel managers' incentive contracts. This study's findings suggest that customer satisfaction measures are significantly associated with future financial performance measures and contain incremental information not reflected in past financial measures. In addition, it was found that both non-financial and financial performance measures (i.e., operating profit, revenue per available room, expense per available room and revenue contribution from toll-free lines) improve following the introduction of an incentive plan that includes non-financial performance measures.

More recently, Riley et al. (2003) examined the value relevance to investors of financial and non-financial performance variables. Riley et al. appraised the impact on stock returns of conventional accounting denominated financial measures (i.e., earnings and changes in abnormal earnings) as well as non-financial performance variables (i.e., customer complaints, revenue load factor, market share and ton miles) for seven of the largest United States airlines. It was found that financial and non- 
financial performance variables are significantly associated with stock returns. Of particular interest is the fact that non-financial performance variables were found to exhibit greater value relevance than traditional financial measures. While traditional financial measures were significantly associated with stock returns, no evidence was found of them providing any incremental explanatory power beyond that provided by the non-financial variables. ${ }^{3}$

Riley et al's (2003) findings provide support for the implementation of a more balanced set of internal performance measures in a manner such as that promoted in Kaplan and Norton's (1992) seminal work on the balanced scorecard. The balanced scorecard incorporates internal and external performance indicators sub-divided according to four main dimensions of focus, one of which concerns a customer perspective. Kaplan and Norton (1992) note that a number of companies have missions that focus on customers. Greater importance attached to customer based performance measures would appear to underscore such a mission. Customer focused performance measures promoted by Kaplan and Norton (1992) include customer satisfaction, customer retention and market share in target segments. It appears as significant that the balanced scorecard represents a performance evaluation framework providing considerable impetus for the marketing and management accounting paradigms assuming a greater degree of common ground.

\footnotetext{
${ }^{3}$ It was found that non-financial variables explained $23 \%$ of the variability in stock returns. Adding EPS and changes in abnormal earnings did not improve the amount of variability explained.
} 


\subsection{Customer Accounting - Investigating Unrealised Potential}

There are several constructs of potential customer accountability that, despite extensive discussion in the marketing literature, have attracted minimal attention in the research based accounting literature or in accounting textbooks. This section of the paper will consider three of the most widely researched marketing orientated customer accountability constructs of customer satisfaction, customer loyalty and customer profitability, and provide a commentary on their potential as objects of accountability that could be added to the strategic management accountant's portfolio of accounting techniques. The selection of these three themes has resulted from a quest to identify those strands of the marketing literature concerned with dimensions of customer focused organisational achievement that provide scope for performance measurement and establishing domains of accountability. The remainder of this section is structured according to an overview of the marketing literature pertaining to these three constructs, with particular attention directed to ways that they may be measured. While customer profitability from an accounting perspective has already been considered, an examination of the marketing literature concerned with customer profitability reveals a number of distinct conceptualisations and lines of enquiry.

\subsection{Customer Satisfaction}

Prior to an exploration of the large marketing literature concerned with customer satisfaction, it is pertinent to note that the balanced scorecard literature widely extols the importance of customer satisfaction. A fundamental challenge arising in any attempt to quantify customer satisfaction stems from the fact that it 
represents a state of mind. Customers compare their expectations prior to a purchase with their performance perceptions after the purchase (Oliver, 1996; Westbrook and Oliver, 1991). The satisfaction literature focuses on customer satisfaction as an outcome of "global satisfaction" (the offer in total), rather than "domain-specific satisfaction" (each part of the offer) (Oliver, 1996). Satisfaction is therefore a cognitive judgment that lies on a continuum ranging between low satisfaction where expectations exceed perceptions of performance, and high level satisfaction where performance is perceived as exceeding initial purchase expectations. As noted by Kotler (2000, p. 36) "There is general agreement that: Satisfaction is a person's feelings of pleasure or disappointment resulting from comparing a product's perceived performance (or outcome) in relation to his or her expectations".

A large body of research has focused on the antecedents and consequences of customer satisfaction (Anderson, Fornell and Lehmann, 1994; Gómez, McLaughlin and Wittink, 2004; Oliver, 1997; Reinartz, Krafft and Hoyer, 2004). The relationship between customer satisfaction, customer loyalty and profitability/performance has received interest from both academics and managers (Donio', Massari and Passiante, 2006; Lowenstein, 1996; Peterson and Wilson, 1992). This interest stems from a widely-held belief that improved customer satisfaction will have a positive effect on business profitability/performance through increased customer loyalty (Anderson, Fornell and Lehmann, 1994; Edvarsson, Johnson, Gustafsson and Strandvik, 2000; Hallowell, 1996; Heskett, Jones, Loveman, Sasser and Schlesinger, 1994; Reichheld, Markey and Hopton, 2000; Reichheld and Sasser, 1990; Rust, Zahorik and Keiningham, 1995; Schneider and Bowen, 1995; Storbacka, Strandvik and Grönroos, 1994). The causal mechanism underlying this linkage is fairly 
straightforward. It is assumed that satisfied customers are more likely to show loyalty to the business via repeat purchases (and increased customer retention). It is also thought that high levels of customer satisfaction will result in increased sales resulting from word of mouth referrals. This view is supported by the findings of several empirical studies (Anderson, Fornell and Mazvancheryl, 2004; Holmes and Lett, 1977; Singh and Pandya, 1991; Swan and Oliver, 1989).

It appears as a cornerstone to marketing theories that customer satisfaction has a positive impact on long-term business performance and a number of empirical studies have found a positive relationship between customer satisfaction and customer loyalty (Anderson and Sullivan, 1993; Donio', Massari and Passiante, 2006; Fornell, 1992; Reichheld and Sasser, 1990; Taylor and Baker, 1994). Other studies have focused on customer retention as a manifestation of customer loyalty, providing evidence of a positive association between customer satisfaction and customer retention (Bearden and Teel, 1982; Ennew and Binks, 1996; LaBarbera and Mazursky, 1983). The positive linkage between customer satisfaction, loyalty and retention, has been posited to favourably impact on a firm's profits as retained customers are cheaper to service than new customers (Anderson, Fornell and Mazvancheryl, 2004; Hallowell, 1996; Reichheld, 1993).

A firm's long term profitability is also expected to benefit from increased customer satisfaction, as retained customers can be less price sensitive. To date, evidence concerning this relationship is mixed, however. While Zeithaml, Berry and Parasuraman (1996) found that price sensitivity was present in particular situations, Anderson (1996) showed that satisfied customers were less price sensitive and less likely to switch when a firm increases prices. 
While there is limited evidence concerning a direct customer satisfaction / profitability link, the above studies provide a strong case for expecting that increased customer satisfaction will have a beneficial impact on financial performance. Research examining the link between satisfaction and performance from a crosssectional perspective has yielded inconclusive findings (Anderson, Fornell and Mazvancheryl, 2004; Boulding, Kalra, Staelin and Zeithaml, 1993; Rust and Zahorik, 1993; Rust, Zahorik and Keiningham, 1995). For example, Yeung and Ennew (2000) found some evidence that satisfaction does have a positive financial impact but that the direct effects were generally small. Nelson, Rust, Zahorik, Rose, Batalden and Siemanski (1992) found a positive relationship between customer satisfaction levels and a range of profitability measures - earnings, net revenues and return on assets. Anderson, Fornell and Lehmann (1994) also provided evidence suggesting heightened customer satisfaction levels increase profitability. On the other hand, Tornow and Wiley (1991) report a negative association between customer satisfaction and profits, and Wiley (1991) suggested that all elements of customer satisfaction were negatively related to financial performance. Interestingly, Bernhardt, Donthu and Kennett (2000) examined the relationship between customer satisfaction and performance in a longitudinal setting and found that while an increase in customer satisfaction had no effect on firm performance in the short run, in the longterm, increased customer satisfaction had a significant positive effect on profits. While more recently, Anderson, Fornell and Mazvancheryl (2004) found a positive association between customer satisfaction and shareholder value that varied significantly across industries and firms. 
A positive relationship between customer satisfaction and non-financial firm performance was documented by Schneider (1991). Further, although Tornow and Wiley (1991) found no association between customer satisfaction and financial performance, their results indicated a positive relationship between customer satisfaction, customer retention and perceptions of product quality.

Relationships between customer satisfaction, service quality and purchase intentions have also been examined. Cronin and Taylor (1992) found a positive relationship between perceived service quality and satisfaction, and satisfaction and intent to repurchase. Several other studies provide support for these findings (Bearden and Teel, 1983; Dabholkar and Thorpe, 1994; LaBarbera and Mazursky, 1983; Oliver, 1980; Oliver and Swan, 1989; Rust and Zahorik, 1993). In an earlier critical review of the consumer satisfaction literature, Yi (1990; p. 104) concluded 'Many studies found that customer satisfaction influences purchase intentions as well as post-purchase attitude'.

\subsection{Customer Loyalty}

Many marketing researchers have argued that retained loyal customers result in increased profits due to decreased costs and increased revenues (Berry and Parasuraman, 1991; Choi, Kim, Kim and Kim, 2006; Kumar and Shah, 2004; Lee, Barker and Kandamputty, 2003; Perrien, Paradis and Banting, 1995; Pitta, Franzak and Fowler, 2006; Sonnenberg, 1994; Zeithaml, Parasuraman and Berry, 1990). It is suggested that loyal customers result in lower costs due to lower acquisition expenses and efficiencies from servicing experienced customers; and revenues are

increased as a result of repeat purchases and customer referrals. Reichheld and 
Sasser (1990) concluded that, depending on the industry, a company could improve profitability by between $25 \%-85 \%$ by reducing customer defections by $5 \%$. Also, Reichheld (1993) claims that in the life insurance industry, a 5\% increase in customer retention reduces the cost per policy by $18 \%$. These factors underscore Srivastava, Shervani and Fahey's (1998) view of customer loyalty as a valuable commercial asset of a business.

Customer loyalty can be defined in two ways (Jacoby and Kyner, 1973). Firstly, loyalty can be defined as an attitude where customer attachment is developed to a product, service, brand or an organisation. From a purely cognitive perspective, such attachment defines a customer's degree of loyalty (Hallowell, 1996). Secondly, loyalty can be defined in terms of behaviour. Yi (1990) provides examples of loyalty behaviour such as continuing to purchase from the same supplier, recommending a particular seller, or increasing the scale of a relationship with a supplier.

Customer loyalty has been a major focus in many industries over recent years as companies seek to increase customer loyalty by instigating loyalty reward programmes such as frequent flyer programmes, loyalty club cards and fly buy cards (Lewis, 1999; Liebermann, 1999). However, recent research has questioned the value of spending marketing resources in an attempt to build loyalty that may or may not result in improved profits (Reinartz and Kumar, 2002). Dowling and Uncles (1997) mirror this sentiment by specifically questioning whether customer loyalty programmes actually work. In support of this view, Reinartz and Kumar (2002) studied four companies from different industries and found that the correlation between profitability and each firm's measure of customer loyalty was weak. This 
suggests customer loyalty programmes are much more strongly linked to customer spending or frequency of usage than customer profitability.

Empirical research concerned with behavioural loyalty has employed a number of different loyalty measures. These measures include probability of purchase (Farley, 1964; Massey, Montgomery and Morrison, 1970), probability of product repurchase (Lipstein, 1959; Kuehn, 1962), proportion of purchase (Cunningham, 1966), purchase frequency (Brody and Cummingham, 1968) and repeat purchase behaviour (Brown, 1952). These measures focus on purchase behaviour or propensity to purchase. Kumar and Shah (2004), however, note that loyalty programmes that reward customer purchase behaviour without linking this behaviour to profitability are likely to fail and point to a number of inadequacies of current loyalty programmes. These inadequacies include the fact that the current measure of profitability used by loyalty programmes focuses on the past (Reinartz and Kumar, 2003) as customers are rewarded for actions made today or actions made in the past accruing from accumulated points. This signifies that loyalty programmes fail to consider the future potential of a customer. This factor can be important as research suggests that customers who have provided profits to a business in the past may not continue to act in the same way in the future (Reinartz and Kumar, 2002; 2003).

Attitudinal loyalty has been defined as a customer's long-term commitment to a business that cannot be deduced by measuring the customer's purchase behaviour. It has often been described in the context of brand loyalty (Kumar and Shah, 2004). Attitudinal loyalty is important as it can indicate a customer's predilection to demonstrate behaviours such as making recommendations about a 
company (Reichheld, 2003) or the probability of future product or service usage (Liddy, 2000). Dick and Basu (1994) believe that failure to account for attitudinal loyalty can lead to misleading gauging of customer loyalty. Like behavioural loyalty, measuring attitudinal loyalty presents some fundamental challenges, it is not surprising therefore that several researchers have advocated the use of both approaches to loyalty measurement (e.g. Day, 1969; Pritchard, Howard and Havitz, 1992).

\subsection{Customer Profitability}

Consistent with the accounting literature, it appears the marketing literature tends to conceive of customer profitability as revenues less costs generated by a customer over a given time period (van Raaij, 2005; van Raaij, Vernooij and van Triest, 2003; van Triest, 2005; Wayland and Cole, 1994). An extension to this approach is offered by Jain and Singh (2002), however, who suggest recognition should also be given to other customer revenues and costs such as customer acquisition and retention costs.

A second departure from the accounting literature concerns the marketing literature's greater consideration given to two distinct customer profitability temporal perspectives. Firstly, customer profitability can be viewed in a manner analogous to the accounting notion of profit, i.e., a historically orientated measure pertaining to a specific past period of time. This type of analysis has been discussed at several different levels of profit reporting level, e.g., gross contribution margin level (Wang and Splegel, 1994) or net profit level (Howell and Soucy, 1990). Additionally, customer profitability has been considered in terms of marketing metrics that identify 
the profitability of marketing expenditures (Helgesen, 2007); managing customer profitability using portfolio matrices (Ang and Taylor, 2005) and financial approaches to customer segmentation (Helgesen, 2005). It has also been considered in a relative sense through the calculation of "customer return on assets", i.e., customer profitability divided by customer oriented assets, i.e., accounts receivable and inventory (Rust, Zahorik and Keiningham, 1996). The second customer profitability time period concerns the future. This form of customer profitability is referred to as the "lifetime value" of the customer (Jain and Singh, 2002). It is most often referred to in terms of some form of net present value calculation (Gupta, Lehmann and Stuart, 2004). For example, Berger and Nasr (1998) describe a basic structural model of customer lifetime value (CLV) as customer revenues less customer costs discounted to present value over the periods of the projected trading relationship with a customer. CLV has also been termed "customer equity" (Bauer and Hammerschmidt, 2005). Blattberg and Deighton (1996) suggested that customer equity could be measured by calculating the expected contribution of each customer, discounting the contributions to the net present value and adding all customer discounted contributions together.

The popularity of CLV stems from it being a forward-looking metric that incorporates revenues, expenses and customer behaviour that drives future profitability (Kumar and Shah, 2004). It is widely claimed that CLV is a superior measure compared to customer profitability because of its forward looking nature (Reinartz and Kumar, 2000). Jain and Singh (2002) in their review article of CLV research in marketing suggest that it is extremely important for marketing management to understand CLV, as CLV models represent an efficient way for firms to evaluate their relationships with customers. 
According to Jain and Singh (2002) the literature on CLV research in mainstream marketing has embarked on a number of distinct directions, with three points of focus being prominent. Firstly, there is a body of research concerned with the development of models to calculate the CLV for each customer. Research in this area has commented on the inclusion of customer acquisition costs, retention costs, other marketing costs and also the customer revenue stream in the determination of CLV. Jain and Singh (2002) describe the second area of CLV research as "customer base analysis". In this analysis, various methods have been proposed to analyse information about the customer base and predict the value of future customer transactions. Researchers have focused on individual customers and customer segments and have used empirical methods to determine which customers should be attracted and retained (Venkatesan and Kumar, 2004). The third area of CLV research has concentrated on analysing the implications of CLV for management decision making through analytical models. Jain and Singh note that a particular interest in this sphere of research concerns the effect of loyalty programmes on CLV and a firm's profitability. Kumar, Shah and Venkatesan (2006) show that maximum positive impact to CLV occurs when the customer cross-purchases, shows multichannel shopping behaviour, stays longer with the firm, buys specific product categories and purchases more frequently with the firm.

CLV models serve a variety of uses in organisations, as they can support strategic as well as tactical decision making (Jain and Singh, 2002). Strategic decision making can be informed by CLV through the identification of a firm's customers, the nature of their characteristics, and which customers should be targeted over the long run (Venkatesan and Kumar, 2004). Tactical decisions can be 
supported in areas such as informing short-term marketing resource allocations and also determining what marketing activities should be pursued (Ryals and Knox, 2005). Knowledge of the potential profit of customers enables firms to develop customer-specific marketing programmes that can increase the efficiency and effectiveness of marketing strategies.

Dwyer (1997) extended the basic CLV model to incorporate a prediction of customer purchase behaviour founded on past purchase behaviour. While Dwyer's model can be seen as an advancement over the basic structural model as it incorporates the random nature of customer purchases, it does still have similar weaknesses such as the time period is fixed, cash flows are assumed to occur at the same time within the same period and predicted customer purchase behaviour depends only on the last purchase period.

Other model advancements have also been suggested. Blattberg and Deighton (1996) proposed a managerial model for finding the optimum balance between spending on customer acquisition and customer retention in order to maximise CLV. Berger and Nasr-Bechwati (2001) proposed a method that uses decision calculus to maximise total customer value by considering the optimal promotional expenditure allocation between customer acquisition, customer retention and other promotional outlays. Pfeifer and Carraway (2000) proposed Markov Chain Models as a method to model both customer retention and customer migration situations. Schmittlein, Morrison and Colombo (1987) proposed the Pareto/NBD model which incorporates a calculation of the probability that a customer is still active. Reinartz and Kumar (2000) propose a model that is an extension of the 
Pareto/NBD model as it incorporates the probability of a customer still being active as a dichotomous "alive/dead" measure.

A close examination of these models reveals that CLV is operationalised in each by considering customer retention as the most important attribute of customer management. Other customer-related attributes such as service usage, cross buying and positive referrals have been typically ignored, although Lee, Lee and Feick (2006) empirically investigate the effect of word of mouth effects in estimating CLV. Further advancements to CLV models can be expected to result once recognition is given to the range of customer behaviours evident in the client base of most medium to large organisations.

Analysis of customer profitability has been particularly important in firms operating direct marketing sales approaches (Shepard, 1990). Even so, Mulhern (1999) notes that there can be difficulties in obtaining accurate information on an individual customer's purchasing behaviour. Measuring customer profitability requires information on customer purchases and variable marketing costs over a period of time. Contrary to this view, Blattberg and Deighton (1991) argue that customer profitability analysis is now increasingly possible because of the availability of customer databases containing a history of customer transactions.

Several studies provide particular insights in connection with customer profitability measurement issues. Schmittlein, Cooper and Morrison (1993) and Mulhern (1999) both provide major overviews of issues confronted in measuring customer profitability. Berger and Nasr (1998) discuss structural modeling aspects for building profitability models. Storbacka (1998) provides a description of customer 
profitability as a fundamental facet of relationship marketing and discusses measures for evaluating the distribution of profitability across customers. Schmittlein, Morrison and Colombo (1987) and Schmittlein and Peterson (1987) provide modeling procedures for determining whether a customer is still active and what to expect in terms of future purchase behaviour. While Berger et al. (2006) address the relationship between CLV and shareholder value.

It appears that customer profitability and customer lifetime value (CLV) have been the subject of increasing attention in recent years (Berger and Nasr, 1998; Gupta et al., 2006; Kumar, Lemon and Parasuraman, 2006; Mulhern, 1999; Reinartz and Kumar, 2000, 2003; Rust, Lemon and Zeithaml, 2004). Mulhern (1999) sees this greater attention given to customer profitability in the marketing literature as strengthening managers' ability to target communications to worthy individual customers.

Wyner (1996) feels that the importance of customer profitability analysis is such that it can reposition the traditional marketing practice by treating the customer as an asset equivalent to other economic units. In this context, marketing decisions are similar to investment decisions as expenditure is evaluated in terms of expected returns. From this perspective, customer profitability becomes an important point of reference in the management of customer relationships (Morgan and Hunt, 1994). Mulhern (1999) suggests that knowledge of customer profitability can improve decision making for many aspects of marketing including service and product development, pricing and all forms of marketing communications including personal selling and promotion. 


\subsection{Discussion and Conclusion}

This paper has attempted to progress a synthesis of the marketing and management accounting literatures concerned with customer accounting. The work represents a novel contribution as it is believed to constitute the first study to draw the two literatures together within the context of a single paper. The extent of any claimed contribution has to be tempered, however, by a need to acknowledge that the synthesis achieved may be characterised as more partial than profound. This is because, in structuring the paper, the decision was made that highlighting the distinct marketing and accounting literatures on customers could be best served by commenting on them sequentially and not as a single integrated whole. While this might be interpreted as a shortcoming of the paper, the need to highlight the distinctive perspectives of the marketing and accounting literatures was believed to be important. Viewed in this light, the paper can be seen to lay important groundwork for any future studies that seek a more profound integration between the marketing and accounting literatures on customer accounting.

The study has revealed that the accounting literature addressing customer accounting can be described as little more than fledgling. This is particularly the case when it is considered in the context of the size and breadth of the marketing literature concerned with customer focused dimensions of organisational performance. This difference between the two literatures is clearly apparent when one reflects on the overview of the customer-oriented accounting and marketing literatures presented in Table 1. When reviewing this table, it should be born in mind that, although representing a greater quantum, the marketing customer focused studies cited 
represent much less of a comprehensive listing than the accounting literature customer focused studies cited.

INSERT TABLE 1 HERE 
Table 1: Summary of Customer-Orientated Accounting and Marketing Literatures

\begin{tabular}{|c|c|c|}
\hline & Accounting Literature & Marketing Literature \\
\hline Customer Accounting & $\begin{array}{l}\text { Foster and Gupta (1994); Guilding et al. } \\
\text { (2001); Guilding and McManus (2002); } \\
\text { Lind and Strömsten (2006) }\end{array}$ & Helgesen (2007) \\
\hline Customer Profitability & $\begin{array}{l}\text { Bellis-Jones (1989); Cooper and Kaplan } \\
\text { (1991a, 1991b, 1991c); Ward (1992); } \\
\text { Foster and Gupta (1994); Smith and } \\
\text { Dikoli (1995); Foster et al. (1996); } \\
\text { Foster and Young (1997); Noone and } \\
\text { Griffin (1999); Andon et al. (2001); } \\
\text { Guilding et al. (2001); Chenhall (2003); } \\
\text { Luft and Shields (2003); Cardinaels et } \\
\text { al. (2004); Davila and Foster (2005); } \\
\text { McManus (2007) }\end{array}$ & $\begin{array}{l}\text { Howell and Soucy (1990); Schmittlein et al. (1993); } \\
\text { Morgan and Hunt (1994); Wang and Splegel } \\
\text { (1994); Wayland and Cole (1994); Rust et al. } \\
\text { (1996); Wyner (1996); Berger and Nasr (1998); } \\
\text { Strobacka (1998); Mulhern (1999); Reinartz and } \\
\text { Kumar (2000); Jain and Singh (2002); van Raaij et } \\
\text { al. (2003); Gupta et al. (2004); Ang and Taylor } \\
\text { (2005); Helgesen (2005); van Raaij (2005); van } \\
\text { Triest (2005); Helgesen (2007) }\end{array}$ \\
\hline $\begin{array}{l}\text { Customer-orientated } \\
\text { Performance Measures }\end{array}$ & $\begin{array}{l}\text { Kaplan and Norton (1992); Abernethy } \\
\text { and Lillis (1995); Perera et al. (1997); } \\
\text { Riley et al. (2003); Bryant et al. (2004); } \\
\text { Banker and Mashruwala (2007); Cäker } \\
\text { (2007); Ismail (2007) }\end{array}$ & \\
\hline Customer Satisfaction & $\begin{array}{l}\text { Ittner and Larcker (1998); Banker et al. } \\
\text { (2000); Ghosh (2005); Cugini et al. } \\
\text { (2007) }\end{array}$ & $\begin{array}{l}\text { Holmes and Lett (1977); Bearden and Teel (1982); } \\
\text { Bearden and Teel (1983); LaBarbera and } \\
\text { Mazursky (1983); Swan and Oliver (1989); } \\
\text { Reichheld and Sasser (1990); Yi (1990); Schneider } \\
\text { (1991); Singh and Pandya (1991); Tornow and } \\
\text { Wiley (1991); Wiley (1991); Westbrook and Oliver } \\
\text { (1991); Cronin and Taylor (1992); Fornell (1992); } \\
\text { Nelson et al. (1992); Peterson and Wilson (1992); } \\
\text { Anderson and Sullivan (1993); Boulding et al. } \\
\text { (1993); Rust and Zahorik (1993); Anderson et al. } \\
\text { (1994); Dabholkar and Thorpe (1994); Heskett et } \\
\text { al. (1994); Storbacka et al. (1994); Taylor and } \\
\text { Baker (1994); Rust et al. (1995); Schneider and } \\
\text { Bowen (1995); Anderson (1996); Edvarsson et al. } \\
\text { (1996); Ennew and Binks (1996); Lowenstein } \\
\text { (1996); Oliver (1996); Zeithaml et al. (1996); } \\
\text { Bernhardt et al. (2000); Reichheld et al. (2000); } \\
\text { Yeung and Ennew (2000); Gómez et al. (2004); } \\
\text { Reinartz et al. (2004); Donio' et al. (2006) }\end{array}$ \\
\hline Customer Loyalty & Smith and Wright (2004) & $\begin{array}{l}\text { Day (1969); Reichheld and Sasser (1990); Yi } \\
\text { (1990); Zeithaml et al. (1990); Berry and } \\
\text { Parasuraman (1991); Fornell (1992); Peterson and } \\
\text { Wilson (1992); Pritchard et al. (1992); Anderson } \\
\text { and Sullivan (1993); Reichheld (1993); Dick and } \\
\text { Basu (1994); Heskett et al. (1994); Sonnenberg } \\
\text { (1994); Storbacka et al. (1994); Taylor and Baker } \\
\text { (1994); Perrien et al. (1995); Rust et al. (1995); } \\
\text { Schneider and Bowen (1995); Hallowell (1996); } \\
\text { Lowenstein (1996); Dowling and Uncles (1997); } \\
\text { Srivastava et al. (1998); Edvarsson et al. (2000); } \\
\text { Liddy (2000); Reichheld et al. (2000); Reinartz and } \\
\text { Kumar (2002); Lee et al. (2003); Reichheld (2003); } \\
\text { Reinartz and Kumar (2003); Kumar and Shah } \\
\text { (2004); Choi et al. (2006); Donio' et al. (2006); Pitta } \\
\text { et al. (2006) }\end{array}$ \\
\hline Customer Lifetime Value & Andon et al. (2001) & $\begin{array}{l}\text { Schmittlein et al. (1987); Blattberg and Deighton } \\
\text { (1996); Dwyer (1997); Berger and Nasr (1998); } \\
\text { Pfeifer and Carraway (2000); Reinartz and Kumar } \\
\text { (2000); Berger and Nasr-Bechwati (2001); Jain } \\
\text { and Singh (2002); Gupta and Lehmann (2003); } \\
\text { Gupta et al. (2004); Kumar and Shah (2004); } \\
\text { Venkatesan and Kumar (2004); Bauer and } \\
\text { Hammershcmidt (2005); Ryals and Knox (2005); } \\
\text { Berger et al. (2006); Kumar et al. (2006); Gupta et } \\
\text { al. 2006); Lee et al. (2006); Villanueva (2007) }\end{array}$ \\
\hline
\end{tabular}


The literature review conducted has yielded little in terms of case based research insights concerning how customers are appropriated between the accounting and marketing functions for internal debate. It is notable, however, that this divide between the accounting and marketing functions might lessen, together with the imbalance in the amount of attention directed to customer issues by accountants and marketers, if an organisational perspective commented on by Chenhall (forthcoming) grows in popularity. Chenhall draws on the works of Ostroff (1999), Schonberger (1996) and Galbraith (2005) to provide an accounting perspective on the evolving 'Horizontal Organization' philosophy to internal organisational structuring. The key distinguishing facet of this philosophy concerns a move away from conventional functionally based internal organisation structures towards more team based multifunctional groupings that have a customer oriented focus. Should this philosophy become a popularised approach, accountants will be drawn closer to marketing colleagues and we could witness the advent of a range of customer oriented accounting procedures that may well lie beyond the scope of the techniques reviewed in this paper.

The current accounting literature on CA appears dominated by a focus on cost allocation procedures, with frequent reference made to activity based costing. The marketing literature on $\mathrm{CA}$ is more broad-ranging with much greater attention directed to less measurable facets of customer related performance, lifetime customer valuation analysis and also ways that CA measures can be used to further decision making and control. Further, there is a much greater range of customer profitability measurement issues acknowledged and explored in the marketing literature. From a review of these two literatures, one is left with little doubt that 
marketing academics see a greater potential in the development and application of customer accounting procedures.

It is notable that a significant accounting development occurring around two decades ago concerned the coining of the term 'cost objects' (Cooper and Kaplan, 1988). A cost object is the construct that is the subject of a costing exercise. This suggests a cost object constitutes a point of accountability. Conventional cost objects have been products or services, however Cooper and Kaplan's work promoted the notion of also costing activities such as machinery set ups, maintaining equipment, inspecting products, etc. Given the attention directed to the availability of choice in determining objects of accountability which has been underscored by Cooper and Kaplan's commentary, it appears we are overdue for similar new objects of accountability developing with respect to customers. From the discussion above, it seems that much that has been written in the marketing literature could serve to take the lead in this regard. The marketing literature's extensive discussion in connection with customer loyalty and customer satisfaction measurement issues appears as particularly pertinent. When the achievements of the marketing literature with respect to such constructs are recognised, the stunted status of CA in the accounting literature is particularly striking.

The lack of accounting research on CA is also surprising when we recognise that one of the four balanced scorecard dimensions of measurement promoted by Kaplan and Norton (1992) is the customer perspective. The balanced scorecard is an accounting innovation that has attracted considerable attention in the practice and research communities alike. In light of this, it appears as anomalous that greater accounting debate directed towards ways to account for customer performance has 
not been forthcoming. Of the three marketing oriented dimensions of customer performance reviewed in this paper, it is notable that customer loyalty and customer satisfaction both command explicit recognition in commentaries on the balanced scorecard. Niven, (2002: p.127) identifies them first and second in his listing of 34 possible customer measures.

Despite this, it appears that customer lifetime value provides greatest promise as the performance dimension that can be most easily assimilated into an accountant's portfolio of performance measures. This is because customer lifetime value is a monetarily denominated measure. If a bank is seeking to determine how much it can justify expending on a promotional campaign at a university campus, the answer would appear to lie in the expected customer lifetime value of accounts that will be opened. As long as the amount spent is not more than the customer lifetime value of the accounts opened, then a positive return on investment will result from the promotional exercise. This suggests customer lifetime value analysis can provide useful quantitative input to a marketing decision. Failure of the accounting function to grasp the nettle in providing such potentially useful information would appear to reinforce claims made around two decades ago concerning a cultural divide between marketing managers and management accountants (Ratnatunga, Pike and Hooley; 1989).

It is notable that the apparently stunted accounting interest in CA continues despite an increased acceptance that non-financial customer related measures of performance can fall within the scope of management accounting. There is now increased recognition that non-financial performance measures are available to management accountants and increased acknowledgement of the important role 
such measures can play in motivating managers (Banker et al, 2000) and the incremental lead indicator information that they can encompass (Ittner and Larcker, 1998; Riley et al, 2003). In light of all of the above, further research designed to determine what factors contribute to accounting's continued lack of interest in customer accounting would be welcome.

In addition to this, further research could build on the initiative of this study in the following ways:

- Those organisations that have adopted the balanced scorecard can be expected to have relatively advanced customer accounting systems due to the fact that one of the four pillars of the balanced scorecard focuses on the customer value creation dimension of performance. In light of this, case study research conducted in organisations that have adopted the balanced scorecard have the potential to advance our understanding of the potential of, and issues surrounding the application of, advanced customer accounting practices. As noted earlier, it appears that the balanced scorecard represents a performance evaluation framework providing considerable impetus for the marketing and management accounting paradigms assuming a greater degree of common ground.

- Case studies designed to determine the nature of particular facets of customer accounting would likely be productive endeavours in business contexts that lend themselves to customer accounting. For example, it is to be expected that valuable insights with respect to leading edge customer accounting practice would be found in banks and insurance 
companies. In both of these contexts, a long standing account can be expected to ensue from a new customer acquisition.

- To date accountants have not entered into discourse concerning the valuation of customer equity. Given accountants' background in performance measurement and financial modelling, there would appear to be an opportunity for accounting commentators to develop customer equity valuation models. A key factor determining marketing's take up of any model developed is likely to be its complexity, as more complex models can be expected to meet with resistance from marketers.

- More accounting research in regard to customer metrics that have received significant attention from marketing researchers (eg, customer satisfaction, customer loyalty, customer retention) and the impact of these customer metrics on firm performance is also to be welcomed. Such research could provide improved understanding of linkages between these customer-oriented constructs and also financial outcomes. 


\section{References}

Abernethy, M.A. and Lillis, A.M. (1995), "The Impact of Manufacturing Flexibility on Management Control System Design", Accounting, Organizations and Society, Volume 20, Number 4, pp. 241-258.

Anderson, E.W., Fornell, C. and Lehmann, D.R. (1994), "Customer Satisfaction, Market Share and Profitability: Findings from Sweden", Journal of Marketing, Volume 58, Number 3, pp. 53-66.

Anderson, E.W., Fornell, C. and Mazvancheryl, S.K. (2004), "Customer Satisfaction and Shareholder Value", Journal of Marketing, Volume 68, pp. 172-185.

Anderson, E.W. and Sullivan, M.W. (1993), "The Antecedents and Consequences of Customer Satisfaction for Firms", Marketing Science, Volume 12, Number 2, pp. 125-143.

Ang, L. and Taylor, B. (2005), "Managing Customer Profitability Using Portfolio Matrices", Journal of Database Marketing \& Customers Strategy Management, Volume 12, Number 4, pp. 298-304.

Banker, R.D., Potter, G. and Srinivasan, D. (2000), "An Empirical Investigation of an Incentive Plan that Includes Nonfinancial Performance Measures", The Accounting Review, Volume 75, Number 1, pp. 65-92.

Banker, R.D. and Mashruwala, R. (2007), "The Moderating Role of Competition in the Relationship Between Nonfinancial Measures and Future Financial Performance", Contemporary Accounting Research, Volume 24, Number 3, pp. 763-793.

Bauer, H.H. and Hammerschmidt, M. (2005), "Customer-based Corporate Valuation: Integrating the Concepts of Customer Equity and Shareholder Value", Management Decision, Volume 43, Number 3, pp. 331-348.

Bellis-Jones, R. (1989), "Customer Profitability Analysis", Management Accounting, Volume 67, Number 2, pp. 26-28.

Berger, P.D., Eechambadi, N., George, M., Lehmann, D.R., Rizley, R. and Venkatesan, R. (2006), "From Customer Lifetime Value to Shareholder Value: Theory, Empirical Evidence and Issues for Future Research", Journal of Service Research, Volume 9, Number 2, pp. 156-167.

Berger, P.D. and Nasr, N.I. (1998), "Customer Lifetime Value: Marketing Models and Applications", Journal of Interactive Marketing, Volume 12, Winter, pp. 17-30.

Berger, P.D. and Nasr-Bechwati, N. (2001), "The Allocation of Promotion Budget to Maximize Customer Equity", OMEGA: The International Journal of Management Science, Volume 29, Number 1, pp. 49-61. 
Bernhardt, K.L., Donthu, N. and Kennett, P.A. (2000), "A Longitudinal Analysis of Satisfaction and Profitability", Journal of Business Research, Volume 47, Number 2, pp. 161-171.

Berry, L.L. and Parasuraman, A. (1991), Marketing Services: Competing Through Quality, Lexington, MA: Free Press/Lexington Books.

Bhimani, A. and Keshtvarz, M.H. (1999), "British Management Accountants: Strategically Orientated", Journal of Cost Management, Volume 13, Number 2, pp. 25-31.

Blattberg, R.C. and Deighton, J. (1996), "Manage Marketing by the Customer Equity Test", Harvard Business Review, Volume 74, Number 4, pp. 136-144.

Boulding, W., Kalra, A., Staelin, R. and Zeithaml, V. (1993), "A Dynamic Process Model of Service Quality: From Expectations to Behavioral Intentions", Journal of Marketing Research, Volume 30, February, pp. 7-27.

Brody, R.P. and Cunningham, S.M. (1968), "Personality Variables and the Consumer Decision Process", Journal of Marketing Research, Volume 5, Number 1, pp. 5057.

Bromwich, M. (1990), "The Case for Strategic Management Accounting: The Role of Accounting Information for Strategy in Competitive Markets", Accounting, Organizations and Society, Volume 15, Number 1, pp. 27-46.

Brown, G.H. (1952), "Brand Loyalty - Fact or Fiction?", Advertising Age, Volume 23, Number 9, pp. 53-55.

Bryant, L., Jones, D.A. and Widener, S.K. (2004), "Managing Value Creation within the Firm: An Examination of Multiple Performance Measures", Journal of Management Accounting Research, Volume 16, pp. 107-131.

Cardinaels, E., Roodhooft, F. and Warlop, L. (2004), "Customer Profitability Analysis Reports for Resource Allocation: The Role of Complex Marketing Environments". ABACUS, Volume 40, Number 2, pp. 238-251.

Chenhall R.H. (forthcoming), "Accounting for the horizontal organization: A review essay", Accounting, Organizations and Society.

Chenhall. R.H. (2003), "Management Control Systems Design Within Its Organizational Context: Findings from Contingency-Based Research and Directions for the Future", Accounting, Organizations and Society, Volume 28, Number 1-2, pp. 127-168.

Chenhall, R.H. and Langfield-Smith, K. (1998a), "Adoption and Benefits of Management Accounting Practices: An Australian Study", Management Accounting Research, Volume 9, Number 1, pp. 1-19.

Choi, D.H., Kim, C.M, Kim, S.I and Kim, S,H. (2006), "Customer Loyalty and Disloyalty in Internet Retail Stores: Its Antecedents and its Effect on Customer 
Price Sensitivity", International Journal of Management, Volume 23, Number 4, pp. 925-936.

Coad, A. (1996), "Smart Work and Hard Work: Explicating a Learning Orientation in Strategic Management Accounting", Management Accounting Research, Volume 7, Number 4, pp. 387-408.

Cooper, R. and Kaplan, R.S. (1988), "Measure Costs Right: Make the Right Decisions", Harvard Business Review, Volume 66, Number 5, pp. 96-103.

Cooper, R. and Kaplan, R.S. (1991a), Kanthal (A). In The Design of Cost Management Systems: Text, Cases and Readings, Englewood Cliffs, New Jersey: Prentice-Hall Inc.

Cooper, R. and Kaplan, R.S. (1991b), Manufacturers Hanover Corporation: Customer Profitability Report. In The Design of Cost Management Systems: Text, Cases and Readings, Englewood Cliffs, New Jersey: Prentice-Hall Inc.

Cooper, R. and Kaplan, R.S. (1991c), Winchell Lighting, Inc. (A). In The Design of Cost Management Systems: Text, Cases and Readings, Englewood Cliffs, New Jersey: Prentice-Hall Inc.

Cronin, J.J. and Taylor, S.A. (1992), "Measuring Service Quality: A Reexamination and Extension", Journal of Marketing, Volume 56, Number 2, pp. 55-68.

Cugini, A., Carù, A, and Zerbini, F. (2007), "The Cost of Customer Satisfaction: A Framework for Strategic Cost Management in Service Industries", European Accounting Review, Volume 16, Number 3, pp. 499-530.

Cunningham, S.M. (1966), "Brand Loyalty - What, Where, How Much?", Harvard Business Review, Volume 34, January-February, pp. 116-128.

Dabholkar, P.A. and Thorpe, D.I. (1994), "Does Customer Satisfaction Predict Shoppers Intentions?" Journal of Consumer Satisfaction, Dissatisfaction, and Complaining Behavior, Volume 7, pp. 161-171.

Davila, A. and Foster, G. (2005), "Management Accounting Systems Adoption Decisions: Evidence and Performance Implications from Early-Stage/Startup Companies", The Accounting Review, Volume 80, Number 4, pp. 1039-1068.

Day, G.S. (1969), "A Two-Dimensional Concept of Brand Loyalty", Journal of Advertising Research, Volume 9, Number 3, pp. 29-35.

Dick, A.S. and Basu, K. (1994), "Customer Loyalty: Toward an Integrated Conceptual Framework", Journal of the Academy of Marketing Science, Volume 22, Number 2, pp. 99-113.

Donio' J., Massari, P. and Passiante, G. (2006), "Customer Satisfaction and Loyalty in a Digital Environment: An Empirical Test," Journal of Consumer Marketing, Volume 23, Number 7, pp. 445-457. 
Dowling, G.R. and Uncles, M. (1997), "Do Customer Loyalty Programs Really Work?", Sloan Management Review, Volume 38, Number 4, pp. 71-82.

Edvarsson, B., Johnson, M.D., Gustafsson, A. and Strandvik, T. (2000), "The Effects of Satisfaction and Loyalty on Profits and Growth: Product versus Services", Total Quality Management, Volume 11, Number 7, pp. 917-928.

Ennew, C.T. and Binks, M.R. (1996), "The Impact of Service Quality and Service Characteristics on Customer Retention: Small Businesses and Their Banks in the UK", British Journal of Management, Volume 7, Number 3, pp. 219-230.

Erevelles, S. and Leavitt, C. (1992), "A Comparison of Current Models of Consumer Satisfaction/Dissatisfaction", Journal of Consumer Satisfaction, Dissatisfaction, and Complaining Behavior, Volume 5, pp. 104-114.

Farley, J.U. (1964), "Why Does Brand Loyalty Vary Over Products?", Journal of Marketing Research, Volume 1, pp. 9-14.

Fornell, C. (1992), "A National Customer Satisfaction Barometer: The Swedish Experience", Journal of Marketing, Volume 56, January, pp. 6-21.

Foster, G. and Gupta, M. (1994), "Marketing, Cost Management and Management Accounting", Journal of Management Accounting Research, Volume 6, pp. 43-77.

Foster, G., Gupta, M. and Sjoblom L. (1996), "Customer Profitability Analysis: Challenges and New Directions", Cost Management, Spring, 5-17.

Foster, G. and Young, S.M. (1997), "Frontiers of Management Accounting Research", Journal of Management Accounting Research, Volume 9, pp. 63-77.

Fournier, S. and Mick, D.G. (1999), "Rediscovering Satisfaction", Journal of Marketing, Volume 63, Number 4, pp. 5-23.

Galbraith, J. (2005), Designing the customer-centric organization, a guide to strategy, structure, and process, Josey-Bass: San Francisco.

Galloway, D. and Waldron, D. (1988), "Throughput Accounting: The Need For a New Language For Manufacturing", Management Accounting, Volume 66, Number 10, pp. 34-35.

Ghosh, D. (2005), "Alternative Measures of Managers' Performance, Controllability, and the Outcome Effect", Behavioral Research in Accounting, Volume 17, pp. 5570.

Gómez, M.I., McLaughlin, E.W. and Wittink, D.R. (2004), "Customer Satisfaction and Retail Sales Performance: An Empirical Investigation", Journal of Retailing, Volume 80, pp. 265-278.

Guilding, C., Cravens, K.S. and Tayles, M. (2000), "An International Comparison of Strategic Management Accounting Practices", Management Accounting Research, Volume 11, Number 1, pp. 113-135. 
Guilding, C., Kennedy, D.J. and McManus, L. (2001), "Extending the Boundaries of Customer Accounting: Applications in the Hotel Industry", Journal of Hospitality and Tourism Research, Volume 25, Number 2, pp. 173-194.

Guilding, C and McManus, L. (2002), "The Incidence, Perceived Merit and Antecedents of Customer Accounting: An Exploratory Note", Accounting, Organizations and Society, Volume 27, Number 1-2, pp. 45-59.

Gupta, S., Hanssens, D., Hardie, B., Kahn, W., Kumar, V., Lin, N., Ravishanker, N. and Sriram, S. (2006), "Modeling Customer Lifetime Value", Journal of Service Research, Volume 9, Number 2, pp. 139-155.

Gupta, S., Lehmann, D.R. and Stuart, J.A. (2004), "Valuing Customers", Journal of Marketing Research, Volume 91, pp. 7-18.

Hallowell, R. (1996), "The Relationships of Customer Satisfaction, Customer Loyalty, and Profitability: An Empirical Study," International Journal of Service Industry Management, Volume 7, Number 4, pp. 27-42.

Helgesen, Ø. (2005), "Customer Segments Based on Customer Account Profitability", Journal of Targeting, Measurement and Analysis for Marketing, Volume 14, Number 3, pp. 225-237.

Helgesen, Ø. (2007), "Customer Accounting and Customer Profitability Analysis for the Order Handling Industry - A Managerial Accounting Approach", Industrial Marketing Management, Volume 36, pp. 757-769.

Heskett, J.L., Jones, T.O., Loveman, G.W., Sasser, W.E. Jr. and Schlesinger, L.A. (1994), "Putting the Service Profit Chain to Work", Harvard Business Review, March-April, pp. 105-111.

Holmes, J.H. and Lett, J.D. (1977), "Product Sampling and Word-of-Mouth Intentions", Journal of Consumer Research, Volume 17, pp. 35-40.

Howell, R.A. and Soucy, S.R. (1990), "Customer Profitability: As Critical as Product Profitability", Management Accounting, October, pp. 43-47.

Ismail, T.H. (2007), "Performance Evaluation Measures in the Private Sector: Egyptian Practice", Managerial Auditing Journal, Volume 22, Number 5, pp. 503513.

Ittner, C.D. and Larcker, D.F. (1998), "Are Nonfinancial Measures Leading Indicators of Financial Performance? An Analysis of Customer Satisfaction", Journal of Accounting Research, Volume 36, pp. 1-35.

Jacoby, J. and Kyner, D.B. (1973), "Brand Loyalty vs. Repeat Purchasing Behaviour", Journal of Marketing Research, Volume 10, Number 1, pp. 1-9. 
Jain, D. and Singh, S.S. (2002), "Customer Lifetime Value Research in Marketing: A Review and Future Directions", Journal of Interactive Marketing, Volume 16, Number 2, pp. 34-46.

Johnson, H.T. (1992), Relevance Regained: From Top-Down Control to Bottom-Up Empowerment, New Jersey: The Free Press.

Johnson, H.T. and Kaplan, R.S. (1987), Relevance Lost: The Rise and Fall of Management Accounting, Boston: Harvard Business School Press.

Juras, P. E. and Dierks, P. A. (1994), "Student Case Competition Case: Blue Ridge Manufacturing", Management Accounting, December, pp. 57-59.

Kaplan, R.S. and Norton, D.P. (1992), "The Balanced Scorecard - Measures that Drive Performance", Harvard Business Review, January-February, pp. 71-79.

Kotler, P. (2000), Marketing Management, International Edition, Englewood Cliffs, NJ: Prentice Hall.

Kuehn, A. (1962), "Consumer Brand Choice as a Learning Process", Journal of Advertising Research, Volume 2, March-April, pp. 10-17.

Kumar, V., Lemon, K.N. and Parasuraman, A. (2006), "Managing Customers for Value: An Overview and Research Agenda", Journal of Service Research, Volume 9, Number 2, pp. 97-94.

Kumar, V. and Shah, D. (2004), "Building Sustaining Profitable Customer Loyalty for the $21^{\text {st }}$ Century", Journal of Retailing, Volume 80, Number 4, pp. 317-329.

Kumar, V., Shah, D. and Venkatesan, R. (2006), "Managing Retailer Profitability One Customer at a Time", Journal of Retailing, Volume 82, Number 4, pp. 277294.

LaBarbera, P.A. and Mazursky, D. (1983), "A Longitudinal Assessment of Consumer Satisfaction/Dissatisfaction: the Dynamic Aspect of the Cognitive Process", Journal of Marketing Research, Volume 20, Number 4, pp. 393-404.

Lee, S.C., Barker, S. and Kandampully, J. (2003), "Technology, Service Quality, and Customer Loyalty in Hotels: Australian Managerial Perspectives", Managing Service Quality, Volume 13, Number 5, pp. 423-432.

Lee, J., Lee, J. and Feick, L. (2006), "Incorporating Word-of-Mouth effects in Estimating Customer Lifetime Value", Database Marketing and Customer Strategy Management, Volume 14, Number 1, pp. 29-39.

Lewis, H.G. (1997), "Does Your "Loyalty" Program Inspire Any Loyalty?", Direct Marketing, Volume 60, Number 2, pp. 46-48.

Liebermann, Y. (1999), "Membership Clubs as a Tool for Enhancing Buyers' Patronage", Journal of Business Research, Volume 45, Number 3, pp. 291-297. 
Liddy, A. (2000), "Relationship Marketing, Loyalty Programmes and the Measurement of Loyalty", Journal of Targeting, Measurement Analysis for Marketing, Volume 8, Number 4, pp. 351-362.

Lind J. and Strömsten, T. (2006), "When Do Firms Use Different Types of Customer Accounting?", Journal of Business Research, Volume 59, pp. 1257-1266.

Lord, B. (1996), "Strategic Management Accounting: The Emperor's New Clothes", Management Accounting Research, Volume 7, Number 3, pp. 347-366.

Lowenstein, M.W. (1996), "Keep Them Coming Back", Marketing Tools, May, pp. 5457.

Luft, J. and Shields, M. (2003), "Mapping Management Accounting: Graphics and Guidelines for Theory-Consistent Empirical Research", Accounting, Organizations and Society, Volume 28, pp. 169-249.

Massey, W.F., Montgomery, D.B. and Morrison, D.G. (1970), Stochastic Models of Buyer Behavior, Cambridge: MIT Press.

McManus, L. (2007), "The Construction of a Segmental Customer Profitability Analysis", Journal of Applied Management Accounting Research, Volume 5, Number 2, pp. 59-74.

Morgan, R.M. and Hunt, S.D. (1994), "The Commitment-Trust Theory of Relationship Marketing", Journal of Marketing, Volume 58, Number 3, pp. 20-38.

Mulhern, F.J. (1999), "Customer Profitability Analysis: Measurement, Concentration, and Research Directions", Journal of Interactive Marketing, Volume 13, Number 1, pp. 25-40.

Nelson, E.C., Rust, R.T., Zahorik, A., Rose, R.L., Batalden, P. and Siemanski, B.A. (1992), "Do Patient Perceptions of Quality Relate to Hospital Financial Performance?", Journal of Health Care Marketing, Volume 12, Number 4, pp. 613.

Niven, P.R. (2002), Balanced Scorecard Step by Step, John Wiley and Sons: New York.

Noone, B. and Griffin, P. (1999), "Managing the Long-Term Profit Yield from Market Segments in a Hotel Environment: A Case Study on the Implementation of Customer Profitability Analysis", Hospitality Management, Volume 18, pp. 111128.

Nyamori, R. O., Perera, M. H. B., \& Lawrence, S. R. (2001), "The concept of strategic change and implications for management accounting research", Journal of Accounting Literature, Volume 20, 62-83.

Oliver, R.L. (1980), "A Cognitive Model of the Antecedents and Consequences of Satisfaction Decisions", Journal of Marketing Research, Volume 17, Number 4, pp. 460-469. 
Oliver, R. L. (1996), Satisfaction: A Behavioral Perspective on the Consumer, New York, NY: McGraw-Hill.

Oliver, R.L. and Swan, J.E. (1989), "Consumer Perceptions of Interpersonal Equity and Satisfaction in Transaction: A Field Survey Approach", Journal of Marketing, Volume 53, Number 2, pp. 21-35.

Ostroff, F. (1999), The horizontal organization, Oxford University Press: New York.

Perera, S., Harrison, G. and Poole, M. (1997), "Customer-Focused Manufacturing Strategy and the Use of Operations-Based Non-Financial Performance Measures: A Research Note", Accounting, Organizations and Society, Volume 22, Number 6, pp. 557-572.

Perrien, J., Paradis, S. and Banting, P.M. (1995), "Dissolution of a Relationship: The Salesforce Perception", Industrial Marketing Management, Volume 24, Number 4, pp. 317-327.

Peterson, R.A. and Wilson, W.R. (1992), "Measuring Customer Satisfaction: Fact and Artifact", Journal of the Academy of Marketing Science, Volume 20, Number 1, pp. 61-71.

Pitta, D., Franzak, F. and Fowler, D. (2006), "A Strategic Approach to Building Online Customer Loyalty: Integrating Customer Profitability Tiers", Journal of Consumer Marketing, Volume 23, Number 7, pp. 421-429.

Pfeifer, P.E. and Carraway, R.L. (2000), "Modeling Customer Relationships as Markov Chains", Journal of Interactive Marketing, Volume 14, Number 2, pp. 4355.

Pritchard, M.P., Howard, D.A. and Havitz, M.E. (1992), "Loyalty Measurement: A Critical Examination and Theoretical Extension", Management Science, Volume 38, Number 7, pp. 155-164.

Ratnatunga, J., Pike R., and Hooley G., (1989), "New Evidence on the Accounting Marketing Interface", British Accounting Review, Volume 21, pp. 351-370.

Reichheld, F.F. (1993a), The Loyalty Effect. Boston, MA: Harvard Business School Press.

Reichheld, F.F. (1993b), "Loyalty-based Management", Harvard Business Review, March-April, pp. 64-73.

Reichheld, F.F. (1996), The Loyalty Effect: The Hidden Force Behind Growth, Profits and Lasting Value, Boston, MA: Harvard Business School Press.

Reicheld, F.F. (2003), "The One Number You Need to Grow", Harvard Business Review, Volume 81, Number 12, pp. 46-54. 
Reichheld, F.F., Markey, R.G. Jr. and Hopton, C. (2000), "The Loyalty Effect - The Relationship Between Loyalty and Profits", European Business Journal, Volume 12, Number 3, pp. 134-141.

Reichheld, F.F. and Sasser, W.E. (1990), "Zero Defections: Quality Comes to Services", Harvard Business Review, Volume 68, Number 5, pp. 105-111.

Reinartz, W.J., Krafft, M. and Hoyer, W.D. (2004), "The Customer Relationship Management Process: Its Measurement and Impact on Performance", Journal of Marketing Research, Volume 91, pp. 293-305.

Reinartz, W.J. and Kumar, V. (2000), "On the Profitability of Long-Life Customers in a Noncontractual Setting: An Empirical Investigation and Implications for Marketing", Journal of Marketing, Volume 64, Number 4, pp. 17-35.

Reinartz, W.J. and Kumar, V. (2002), "The Mismanagement of Customer Loyalty", Harvard Business Review, Volume 80, Number 7, pp. 86.

Reinartz, W.J. and Kumar, V. (2003), "The Impact of Customer Relationship Characteristics on Profitable Lifetime Duration", Journal of Marketing, Volume 67, Number 1, pp. 77-99.

Riley, R.A., Pearson, T.A. and Trompeter, G. (2003), "The Value Relevance of Nonfinancial Performance Variables and Accounting Information: The Case of the Airline Industry", Journal of Accounting and Public Policy, Volume 22, pp. 231-254.

Roslender, R. and Hart, S.J. (2003), In Search of Strategic Management Accounting: Theoretical and Field Study Perspectives", Management Accounting Research, Volume 14, Number 3, pp. 255-279.

Rust, R.T., Lemon, D. and Zeithaml, V.A. (2004), "Return on Marketing: Using Customer Equity to Focus Marketing Strategy", Journal of Marketing, Volume 68, Number 1, pp. 109-127.

Rust, R.T. and Zahorik, A.J. (1993), "Customer Satisfaction, Customer Retention, and Market Share", Journal of Retailing, Volume 69, Number 2, pp. 193-215.

Rust, R.T., Zahorik, A.J. and Keiningham, T. (1995), "Return on Quality (ROQ): Making Service Quality Financially Accountable", Journal of Marketing, Volume 59, Number 2, pp. 58-70.

Ryals, L.J. and Knox, S. (2005), "Measuring Risk-Adjusted Customer Lifetime Value and its Impact on Relationship Marketing Strategies and Shareholder Value", European Journal of Marketing, Volume 39, Number 5/6, pp. 456-472.

Schneider, B. (1991), "Service Quality and Profits: You Can Have Your Cake and Eat it Too", Human Resource Planning, Volume 14, Number 2, pp. 151-157.

Schneider, B. and Bowen, D.E. (1995), Winning the Service Game, Boston, M.A.: HBS Press. 
Schonberger, R.J. (1996), World class manufacturing: The next decade, The Free Press: New York.

Schmittlein, D.G., Cooper, L.G. and Morrison, D.G. (1993), "Truth in Concentration in the Land of (80/20) Laws", Marketing Science, Volume 12, Number 2, pp. 167183.

Schmittlein, D.G., Morrison, D.G. and Colombo, R. (1987), "Counting Your Customers: Who Are They and What Will They Do Next?", Management Science, Volume 33, January, pp. 1-24.

Schmittlein, D.G. and Peterson, R.A. (1994), "Customer Base Analysis: An Industrial Purchase Process Application”, Marketing Science, Volume 13, Winter, pp. 41-67.

Shepard, D. (1990), The New Direct Marketing, Homewood, IL: Business One Irwin.

Shields, M.D. (1997), "Research in Management Accounting by North Americans in the 1990s", Journal of Management Accounting Research, Volume 9, pp. 3-61.

Simmonds, K. (1981), "Strategic Management Accounting", Management Accounting, Volume 59, Number 4, pp. 26-29.

Singh, J.E. and Pandya, S. (1991), "Exploring the Effects of Complaint Behaviours", European Journal of Marketing, Volume 25, Number 9, pp. 7-21.

Smith, M. and Dikolli, S. (1995), "Customer Profitability Analysis: An Activity-Based Costing Approach", Managerial Auditing Journal, Volume 10, Number 7, pp. 3-7.

Smith, R.E. and Wright, W.F. (2004), "Determinants of Customer Loyalty and Financial Performance", Journal of Management Accounting Research, Volume 16, pp. 183-205.

Sonnenberg, F.K. (1994), "The Age of Intangibles", Management Review, Volume 83, Number 1, pp. 49-53.

Spreng, R. A. and Page, T.J. Jr. (2001), "The Impact of Confidence in Expectations on Consumer Satisfaction", Psychology and Marketing, Volume 18, Number 11, pp. 1,187-1,204.

Srivastava, R.K., Sherwani, T.A. and Fahey, L. (1998), "Market-Based Assets and Shareholder Value: A Framework for Analysis", Journal of Marketing, Volume 62, Number 1, January, pp. 2-18.

Storbacka, K. (1998), "Segmentation Based on Customer Profitability - Retrospective Analysis of Retail Bank Customer Bases", Journal of Marketing Management, Volume 13, pp. 479-492.

Storbacka, K., Strandvik, T. and Grönroos, C. (1994), "Managing Customer Relationships for Profit: The Dynamics of Relationship Quality", International Journal of Service Industry Management, Volume 5, Number 5, pp. 21-38. 
Swan, J.E. and Combs, L.J. (1976), "Product Performance and Consumer Satisfaction: A New Concept", Journal of Marketing, Volume 40, Number 2, pp. 2533.

Swan, J.E. and Oliver, R.L. (1989), "Postpurchase Communications by Consumers", Journal of Retailing, Volume 65, Number 4, pp. 516-533.

Taylor, S.A. and Baker, T.L. (1994), "An Assessment of the Relationship Between Service Quality and Customer Satisfaction in the Formation of Consumers' Purchase Intentions", Journal of Retailing, Volume 70, Number 2, pp. 163-178.

Tomkins, C. and Carr, C. (1996), "Introduction to the Special Issue on Strategic Management Accounting", Management Accounting Research, Volume 7, Number 2, pp. 165-167.

Tornow, W.W. and Wiley, J.W. (1991), "Service Quality and Management Practices: A Look at Employee Attitudes, Customer Satisfaction and Bottom-Line Consequences", Human Resource Planning, Volume 14, Number 2, pp. 105-115.

Tse, D.K. and Wilton, P.C. (1988), "Models of Consumer Satisfaction Formulation: An Extension", Journal of Marketing Research, Volume 24, August, pp. 204-212.

van Raaij, E.M. (2005), "The Strategic Value of Customer Profitability Analysis", Marketing Intelligence \& Planning, Volume 23, Number 4/5, pp. 372-381.

van Raaij, E.M., Vernooij, M.J.A. and van Triest, S. (2003), "The Implementation of Customer Profitability Analysis: A Case Study", Industrial Marketing Management, Volume 32, pp. 573-583.

van Triest, S. (2005), "Customer Size and Customer Profitability in Non-Contractual Relationships", The Journal of Business and Industrial Marketing, Volume 20, Number 2/3, pp. 148-155.

Venkatesan, R. and Kumar, V. (2004), "A Customer Lifetime Value Framework for Customer Selection and Resource Allocation Strategy", Journal of Marketing, Volume 68, pp. 106-125.

Villanueva, J. (2007), Customer Equity: Measurement, Management and Research Opportunities, Now Publishers Inc: Boston.

Wang, P. and Splegel, T. (1994), "Database Marketing and Its Measurement of Success", Journal of Direct Marketing, Volume 8, Number 2, pp. 73-84.

Ward, K. (1992), Accounting for Marketing Strategies. In Drury, C. (ed.). Management Accounting Handbook, Oxford: Butterworth-Heinemann.

Wayland, R.E. and Cole, P.M. (1994), "Turn Customer Service into Customer Profitability", Management Review, Volume 83, Number 7, pp. 22-24. 
Westbrook, R.A. and Oliver, R.L. (1991), "The Dimensionality of Consumption Emotion Patterns and Consumer Satisfaction", Journal of Consumer Research, Volume 18, June, pp. 84-91.

Wiley, J.W. (1991), "Customer Satisfaction: A Supportive Work Environment and Its Financial Costs”, Human Resource Planning, Volume 14, Number 2, pp. 117-127.

Wyner, G.A. (1996), "Customer Profitability: Linking Behavior to Economics", Marketing Research, Volume 8, Number 2, pp. 36-38.

Yeung, M.C.H. and Ennew, C.T. (2000), "From Customer Satisfaction to Profitability", Journal of Strategic Marketing, Volume 8, Number 2, pp. 313-326.

Yi, Y. (1990), A Critical Review of Consumer Satisfaction. In Zeithaml, V. (ed.). Review of Marketing, Chicago, IL: American Marketing Association.

Zeithaml, V.A., Berry, L.L. and Parasuraman, A. (1996), "The Behavioural Consequences of Service Quality", Journal of Marketing, Volume 60, Number 2, pp. 31-46.

Zeithaml, V.A., Parasuraman, A. and Berry, L.L. (1990), Delivering Quality Service, New York, NY: The Free Press. 